\title{
PELAKSANAAN BIMBINGAN KELOMPOK UNTUK MENINGKATKAN EMPATI SISWA KELAS VII DI SMP NEGERI 7 SINGKAWANG
}

\author{
Marice $^{1)}$, Iip Istirahayu ${ }^{2)}$, Slamat Fitriyadi ${ }^{3)}$ \\ 1) Prodi Bimbingan dan Konseling STKIP Singkawang, Singkawang, Indonesia \\ Email: risamarysaputry@gmail.com \\ 2) Prodi Bimbingan dan Konseling STKIP Singkawang, Singkawang, Indonesia \\ E-mail: iip_istirahayu@yahoo.com \\ ${ }^{3)}$ Prodi Bimbingan dan Konseling STKIP Singkawang, Singkawang, Indonesia \\ E-mail: ahmadfitriyadi521@gmail.com
}

\begin{abstract}
Abstrak. Penelitian ini berdasarkan fenomena yang ada di SMP Negeri 7 Singkawang menunjukkan masih rendahnya empati siswa. Melalui bimbingan kelompok diharapkan empati siswa dapat ditingkatkan. Tujuan penelitian ini adalah untuk mengetahui pelaksanaan bimbingan kelompok untuk meningkatkan empati siswa kelas VII C di SMP Negeri 7 Singkawang. Jenis penelitian yang digunakan adalah kualitatif deskriptif. Populasi dalam penelitian yaitu seluruh siswa kelas VII di SMP Negeri 7 Singkawang. Cara pengambilan sampel menggunakan teknik simple random sampling sebanyak 8 siswa di kelas VII C. Hasil penelitian menunjukkan bahwa pelaksanaan bimbingan kelompok pada pertemuan pertama siswa kebanyakkan tidak menanggapi teman yang sedang menyampaikan pendapat. Hanya ada satu siswa yang mampu menunjukkan empatinya seperti menghargai teman yang sedang berbicara dengan cara merespon dan memberi tanggapan, siswa ini digolongkan dengan indikator empati. Pertemuan kedua ada enam siswa sudah mencakup indikator empati memikirkan, memahami, merasakan dan mengkomunikasikan seperti siswa aktif bertanya, berani mengemukakan pendapatnya dan mampu merespon tanggapan temannya. Pertemuan ketiga kali ini semua siswa sudah aktif berargumen dan bertanya tanpa ditunjuk oleh pemimpin kelompok. Hal ini menunjukkan bahwa indikator empati telah diwujudkan oleh setiap siswa
\end{abstract}

Kata Kunci: Pengaruh Layanan Bimbingan Kelompok; Minat Belajar Siswa

\section{Pendahuluan}

Pada hakikatnya manusia adalah makhluk sosial yang saling membutuhkan orang lain. Dalam kehidupan bermasyarakat, individu menemukan orang dengan watak yang berbeda-beda. Individu yang satu tidak memaksakan pendapat, pikiran dan perasaannya kepada orang lain. Artinya setiap individu diharapkan untuk mampu memahami perasaan orang lain.

Dalam hidup bermasyarakat empati berperan penting karena dengan empati individu dapat menyesuaikan diri, mudah menjalin hubungan dengan orang lain, meningkatkan harga diri, dan meningkatkan pemahaman diri [1].
Kemampuan seseorang untuk bisa menghayati perasaan orang lain atau merasakan sesuatu yang dirasakan orang lain disebut empati [2]. Individu dengan kemampuan empati yang tinggi akan mampu mempengaruhi kecakapan sosialnya. Semakin tinggi kecakapan sosialnya, maka individu akan mampu membentuk hubungan, menggerakkan dan mengilhami orang lain, membina kedekatan hubungan, meyakinkan dan mempengaruhi, serta membuat orang lain merasa nyaman. Dengan demikian, orang yang memiliki empati tinggi akan mempunyai etika moral yang tinggi dalam masyarakat. Sebaliknya individu dengan empati yang rendah tidak mampu untuk menyelami pikiran dan perasan orang lain, serta tidak dapat saling memahami satu dengan yang lain. 
Kenyataan yang terjadi di lapangan, berdasarkan observasi dan wawancara dengan guru di sekolah SMPN 7 Singkawang, sebagian besar dijumpai siswa yang kurang memiliki sikap empati baik terhadap guru maupun teman sebaya. Sikap dari kurangnya empati siswa terhadap guru ditunjukan dengan perilaku siswa yang kurang memperhatikan guru ketika sedang menjelaskan materi pelajaran. Sedangkan terhadap teman sebaya, rasa kurang empati ditunjukan dengan perilaku menertawakan teman yang melakukan kesalahankesalahan kecil seperti kesulitan dalam menjawab soal di depan kelas.

Berdasarkan uraian latar belakang masalah di atas, maka peneliti tertarik melakukan penelitian dengan judul "Pelaksanaan Bimbingan Kelompok Untuk Meningkatkan Empati Siswa Kelas VII Di SMP Negeri 7 Singkawang,'.

\section{METODE}

Jenis penelitian ini adalah penelitian kualitatif deskriptif. Dimana pelaksanaan bimbingan kelompok dilaksanakan sebanyak 3 kali pertemuan dengan tujuan untuk menggambarkan hasil pelaksanaan bimbingan kelompok terhadap empati siswa.

Populasi adalah wilayah generalisasi yang terdiri atas objek/subjek yang mempunyai kualitas dan karakteristik tertentu yang ditetapkan oleh peneliti untuk dipelajari dan kemudian ditarik kesimpulannya [3]. Populasi dalam penelitian ini adalah seluruh siswa kelas VII di SMPN 7 Singkawang. Teknik pengambilan sampel yang digunakan adalah teknik simple random sampling dengan 8 siswa di kelas VII C.

\section{HASIL DAN PEMBAHASAN}

\section{A. Hasil}

Pelaksanaan bimbingan kelompok terhadap empati siswa kelas VII C di SMP Negeri 7 Singkawang

Pertemuan 1

Tanggal : 9 April 2016

Materi : Membaca atau Memahami Pikiran orang lain

Pada tahap pembukaan dibuka dengan salam dan berdoa. Pemimpin kelompok maupun anggota saling memperkenalkan diri, perkenalan diawali dari pemimpin kelompok yaitu pemimpin kelompok kemudian dilanjutkan oleh anggota secara bergantian mulai dari nama. Namun suasana yang terlihat sepi karena anggota masih saling diam, meskipun diantara mereka sudah saling kenal. Akan tetapi pemimpin kelompok terus memotivasi agar anggota tidak ragu didalam kelompok. Selanjutnya pemimpin kelompok memberikan sebuah permainan yang bernama "tiga dot" pemimpin kelompok menjelaskan peraturan dan cara untuk bermain, semua anggota kelompok senang dengan permainan tersebut. Kemudian pemimpin kelompok menjelaskan pengertian bimbingan kelompok, tujuan bimbingan kelompok, asas-asas bimbingan kelompok dan cara melaksanakan kegiatan bimbingan kelompok. Tahap selanjutnya pemimpin menanyakan kepada anggota apakah siap untuk mengikuti tahap selanjutnya. Para anggota menjawab siap untuk mengikuti tahap selanjutnya. Dalam tahap kegiatan, pemimpin kelompok mengemukakan materi yang akan dibahas yaitu topik yang pertama yaitu memahami pikiran orang lain. Pemimpin kelompok membatasi sub topik yang akan dibahas yaitu pengertian, dan manfaat, tujuan memahami pikiran orang lain bagi diri dan lingkungan masyarakat. Topik ini bertujuan agar anggota kelompok memahami betapa pentingnya memahami orang lain dan agar anggota dapat mengembangkan pola pikir mereka untuk terpacu berpikir lebih dewasa lagi. Pada mulanya hanya satu anggota yang mengetahui tentang bagaimana memahami pikiran orang lain sehingga pemimpin kelompok melemparkan pertanyaan kepada anggota kelompok yang tahu itu, lalu memberikan argumennya. Akan tetapi masih terlihat beberapa anggota yang masih diam atau ragu dalam mengungkapkan argumennya.

Deskripsi

Tahap awal kehadiran anggota kelompok dalam bimbingan kelompok pertemuan pertama ini masih kurang lengkap karena satu anggota kelompok yang tidak hadir. Bimbingan kelompok tahap pertama ini berjumlah 7 siswa, dengan nama inesial DE, GE, HK, NE, UL, YE, dan EP. Dari pengamatan peneliti partisipasi anggota kelompok ini hanya ada 2 siswa yang mampu atau mau mengeluarkan pendapatnya Yaitu DE dan EF, sedangkan 5 anggota lainnya masih malu-malu serta kurang percaya diri dalam memberikan pendapat yaitu YE, NE, GE, HK dan UL. Dari awal pemimpin kelompok (PK) memulai pelaksanaan bimbingan kelompok dengan mengikuti prosedur dalam kegiatan kelompok, seluruh anggota kelompok dapat mengikuti dengan baik, artinya tidak ada keluar masuk dengan alasan yang tidak penting lainnya. Selama proses bimbingan kelompok ini semua anggota kelompok terlihat antusias. Pada tahap kegiatan inti PK memulai menanyakan kepada anggota kelompok tentang bagaimana memahami pikiran orang lain, dan saat itu hanya ada satu siswa yang secara cepat merespon yaitu GE. PK meminta GE untuk menjelaskan bagaimana cara kita memahami pikiran orang lain, dengan spontan GE menanggapinya dan memberikan contoh nyata yang terjadi di dalam dirinya seperti berikut : "misalnya kita bisa memahami pikiran orang lain dengan cara memahami keadaan situasi orang lain, kemudian kita juga benar-benar masuk kedalam diri orang lain tersebut dengan arti kata harus mampu melihat posisinya sehingga kita dengan mudah memahami situasi dan kondisi yang dialami orang tersebut, contohnya pada saat saya mau meminta sesuatu dengan orang tua, saya harus melihat dulu suasana dan situasi dengan tepat, karena saya tahu apa sebab dan akibatnya.

Tidak ada anggota lain yang memberikan tanggapan selain GE, kemudian PK menanggapi permasalahan yang dialami oleh GE. PK bertanya kepada GE, kalau boleh tahu apa kamu pernah kesulitan memahami pikiran orang lain? GE berkata lagi “iya bu saya pernah'.Maka disitulah saya belajar dari pengalaman, sehingga saya berusaha untuk bisa memahami pikiran orang lain. Dari beberapa anggota kelompok masih belum terlihat yang berani memberikan respon. Karena suasana dalam kelompok terlihat hening maka 
PK menuntun anggota untuk mengemukakan argumennya. HK dengan percaya diri mengacungkan tangan dan mengemukakan argumennya "supaya kita bisa memahami pikiran orang lain kita harus benar-benar masuk dalam keadaan orang dan tidak lupa selalu bawa kepada diri kita bahwa apa yang orang lain rasakan dan alami kita juga merasakan hal yang sama". Kemudian PK membahas permasalahan yang dikemukan oleh anggota kelompok secara tuntas dan dalam kegiatan ini seluruh siswa mengikuti dengan baik.

1) Dinamika Kelompok

Dinamika pada pertemuan pertama ini kurang serius karena masih terfokus kepada PK yang memancing anggota kelompok untuk mengeluarkan pendapatnya karena dari ke tujuh orang dari anggota kelompok tersebut masih terdapat lima orang siswa yang kurang percaya diri untuk berinteraksi dan berargumentasi. Hal ini terlihat pada percakapan PK yang menunjuk salah satu anggota kelompok untuk mengemukakan argumennya. Tanpa mengeluarkan argumennya GE menjawab "ya saya setuju".

2) Suasana Kelompok

Suasana kelompok pada pertemuan pertama ini kurang menyenangkan. Karena masih ada lima siswa yang bingung, gerogi, kaku serta tidak aktif sehingga selama bimbingan kelompok suasana masih sedikit tegang, dan anggota kelompok lebih memperhatikan temannya yang bicara dan kurang fokus saat temannya menanggapi, dan disini yang aktif hanya GE selain itu kebanyakan PK.

3) Reaksi Anggota kelompok

Anggota kelompok yang aktif hanya 2 orang siswa yaitu GE dan HK. Dan lima diantaranya masih belum aktif yakni DE, NE, UL, YE dan EP. Mereka mengeluarkan pendapat ketika PK memintanya untuk berpendapat. Intraksi antar sesama siswa dalam kelompok ini terjalin baik, hal tersebut terlihat siswa saling bercanda saat diberikan waktu untuk berargumen, dan disitulah keadaan mulai mencair.

Pertemuan 2

Tanggal : 13 April 2016

Materi : Membaca atau Memahami Pikiran orang lain

Pada tahap pembukaan dibuka dengan salam dan berdoa, selanjutnya saling menanyakan kabar masing-masing, dan satu anggota baru hadir serta langsung memperkenalkan diri. Setelah itu mengingatkan kembali tentang cara-cara pelaksanaan bimbingan kelompok seperti pada saat pertemuan sebelumnya, pada pertemuan kedua ini jumlah anggota sudah lengkap, karena pertemuan kedua sudah lengkap anggota, maka dilanjutkan tahap kegiatan. Dalam tahap peralihan ini PK menanyakan kesiapan anggota kelompok untuk memasuki tahap selanjutnya. Pada tahap ini PK melanjutkan materi yang sudah disampaikan pada pertemuan pertama.

Deskripsi

Pada pertemuan kedua ini sudah lengkap dengan nama anggota inesial AL, DE, GE, HK, NE, UL, YE, dan EP. topik yang dibahas masih sama dengan pertemuan pertama. Pada tahap pertemuan kali ini, dinamika kelompok terlihat sudah baik karena semua anggota kelompok sudah berpartisipasi. Pada pertemuan ini semua anggota kelompok terlihat sangat aktif dan sangat merespon terhadap topik yang dibahas. Masing-masing anggota kelompok sudah berani mengemukakan apa yang menjadi ide dan pendapatnya terhadap topik yang dibahas. Begitu juga dengan YE, UL, DE, $\mathrm{EP}, \mathrm{AL}$ dan NE juga sudah terlihat aktif mengemukakan pendapatnya. Saat pemimpin kelompok bertanya kepada anggota kelompok tentang cara memahami pikiran orang lain serta bagaimana memposisikan diri kita dengan keadaan orang lain, anggota kelompok langsung mengemukakan argumennya salah satu anggota AL yaitu "kita harus merasakan apa yang orang lain rasakan dan ketika kita sudah merasakan apa yang dialami orang lain tidak menutup kemungkinan kita sudah masuk kehidupan orang lain'”. Sama hal dengan teman yang lain juga berargumen hampir sama dengan AL. setelah itu PK menyimpulkan argument-argumen yang dilomtar oleh anggota kelompok mengenai memahami pikiran orang lain yaitu bahwa cara kita memahami pikiran orang lain adalah dengan kita masuk kedalam kehidupan mereka dan merasakan pahit manisnya yang dialami oleh orang lain juga dirasakan oleh kita.

Pembahasan topik ini sudah luas dibahas, sehingga anggota kelompok dapat memahami dan melakukan apa yang didapatkan dalam bimbingan kelompok dalam kehidupannya sehari-hari.

\section{Pertemuan 3}

Tanggal : 15 April 2016

Materi : Membaca atau Memahami Pikiran orang lain

Pada tahap pembukaan diawali dengan doa dan menanyakan kabar kepada anggota kelompok. Kemudian PK mengingati cara-cara kegiatan kelompok. PK bertanya kepada anggota tentang kesiapan dalam melanjutkan tahap kegiatan.

Deskripsi

Pada pertemuan ketiga kali ini sangat berbeda dengan pertemuan sebelumnya dimana diantara 8 anggota sudah aktif berargumen. YE yang mulanya diam tiba-tiba bersuara. Dilanjut dengan NE bertanya " bagaiman jika kita tidak dapat memahami kondisi orang lain" PK menyerahkan kepada anggota siapa yang dapat memberikan penjelasan terhadap pertanyaan NE. AL mengangkat tangan " istilah jika kita sakit, kita tahukan kondisi tubuh kita, begitu juga jika kita memahami kondisi orang lain hal yang pertama kita lakukan adalah kita mendekati orang tersebut dan berkomunikasi yang baik dengan dia, maka disitulah kita tahu kesulitan yang dialami orang tersebut. PK memberikan tepuk tangan kepada NE dan AL yang sudah memberikan penjelasan dengan baik. UL mengemukakan pendapatnya " contoh disaat saya sulit mengerjakan tugas, saya binggung hal apa yang dilakukan, bearti kondisi saya sedang tidak tenangkan, hal yang saya lakukan adalah saya bertanya kepada orang yang tahu seperti guru dan teman sekelas, tetapi yang perlu saya jelaskan disini, ketika kita dapat memahami diri kita barulah kita dapat memahami kondisi orang lain, kemudian anggota 
memuji UL. Dari masing-masing anggota saling mengemukakan pendapat dan menuangkan ide-idenya.

Dalam pertemuan terakhir ini dapat terwujud dinamika kelompok, Hal ini menunjukkan bahwa indikator empati telah dapat dicapai. Pada tahap pengakhiran PK mengungkapkan kesimpulan hasil pembahasan topik dan memberikan kesempatan bagi anggota kelompok untuk mengungkapkan pesan, kesan, dan harapan terhadap kegiatan bimbingan kelompok. PK mengucapkan terimakasih kepada anggota bimbingan kelompok. Kegiatan diakhiri dengan doa dan salam penutup.

\section{B. Pembahasan}

Bimbingan kelompok adalah salah satu alternatif yang dilakukan untuk meningkatkan empati siswa. Peningkatan empati siswa dapat dilihat dari setiap pertemuan pertama, kedua dan ketiga. Pada pertemuan pertama dijelaskan bahwa terdapat dua siswa GE dan HK yang aktif artinya berani berkomentar dan berantusias dalam bertanya tentang topik yang dibahas, sedangkan siswa yang lainnya hanya diam dan berbicara ketika ditanya oleh pemimpin kelompok. Pertemuan kedua sebagian siswa sudah mulai aktif berbicara yaitu YE, UL, DE, EP, AL dan NE, hal ini dilihat dari siswa mampu berargumen, berani bertanya dan membantu teman yang kesulitan dalam menyampaikan pendapatnya. Selanjutnya pada pertemuan yang ketiga atau terakhir sangat berbeda dari pertemuan pertama dan kedua, karena semua siswa AL, DE, EP, GE, HK, NE, UL dan YE sudah mengalami perubahan yang jauh lebih baik dibandingkan pada awalnya diam, tidak mau berbicara dan ragu-ragu, tiba-tiba berbicara dan saling mengemukankan pendapatnya.

\section{KESIMPULAN}

Berdasarkan hasil yang telah dilakukan peneliti mengenai pelaksanaan bimbingan kelompok pada setiap pertemuan pertama, kedua dan ketiga, maka dapat ditarik kesimpulan dari keseluruhan pertemuan mengenai pelaksanaan bimbingan kelompok menujukan bahwa dari delapan siswa mengalami peningkatan empati yang signifikan.

\section{DAFTAR PUSTAKA}

[1] Septi, W, dkk. (2012). Upaya Meningkatkan Empati Dalam Berinteraksi Sosial Melalui Dinamika Kelompok Pendekatan Experiential Learning. Jurnal Bimbingan dan Konseling. Fakultas Ilmu Pendidikan. Semarang: UNNES.

[2] Ade, Masturi. (2010). Membangun Relasi Sosial Melalui Komunikasi Empatik (perspektif Psikologi Komunikasi). Jurnal Dakwah dan Komunikasi Stain Purwokerto Vol. 4. No. 1 PP. 14. 31 ISSN : $1978-$ 1261.

[3] Sugiyono. (2007). Metode Penelitian Bisnis. Bandung: Alfabeta. 